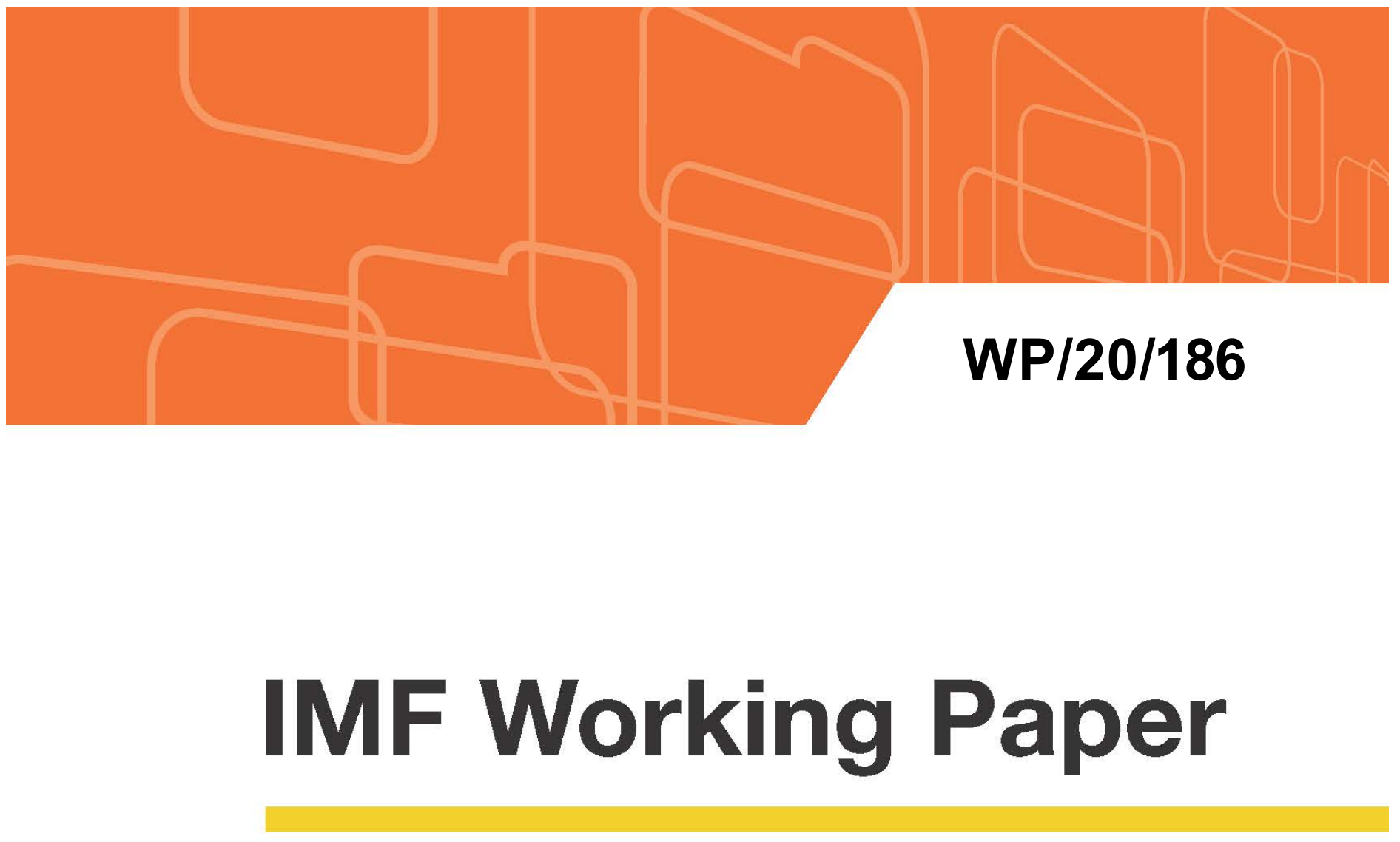

\title{
What Drives Bank Lending Spreads and Collateral Requirements in the Kyrgyz Republic
}

by lulia Ruxandra Teodoru

IMF Working Papers describe research in progress by the author(s) and are published to elicit comments and to encourage debate. The views expressed in IMF Working Papers are those of the author(s) and do not necessarily represent the views of the IMF, its Executive Board, or IMF management. 


\title{
IMF Working Paper
}

Middle East and Central Asia Department

\section{What Drives Bank Lending Spreads and Collateral Requirements in the Kyrgyz Republic}

\section{Prepared by Iulia Ruxandra Teodoru}

Authorized for distribution by Nicolas Blancher

September 2020

IMF Working Papers describe research in progress by the author(s) and are published to elicit comments and to encourage debate. The views expressed in IMF Working Papers are those of the author(s) and do not necessarily represent the views of the IMF, its Executive Board, or IMF management.

\begin{abstract}
Limited access to finance and its high cost have contributed to relatively low levels of private investment and subpar growth in the Kyrgyz Republic. Interest rate spreads have moderated in recent years, but remain high from both a regional and global perspective. At the same time, collateral requirements applied by banks are onerous and also constrain the quantity of credit supplied. This paper identifies a range of factors that could lower spreads in the Kyrgyz Republic: more competition, higher capital, lower credit risk, larger loan size, lower deposit rates and external funding costs, as well as a stronger legal framework. Lower operating costs appear critical to reduce relatively higher spreads for small and medium-sized banks. At the same time, a stronger legal framework and greater transparency on borrowers' creditworthiness would help reduce the high collateral requirements. Reforms in all these areas would support greater financial inclusion in the aftermath of the pandemic, and could thus be a key source of sustainable and inclusive growth in the Kyrgyz Republic.

JEL Classification Numbers: E43, E44, G21, O54
\end{abstract}

Keywords: Bank lending spreads, financial intermediation

Author's E-Mail Address: iteodoru@imf.org 


\section{INTRODUCTION ${ }^{1}$}

Limited access to finance for SMEs and its high cost are likely one of the main reasons for the relatively low level of private investment and subpar growth in the Kyrgyz Republic. Levine (1997 and 2004) found that insufficient financial intermediation is an important obstacle to growth. Access to finance is one of the key constraints for firms in the Kyrgyz Republic. Access of firms to a bank loan (25.8 percent) or share of investment financed by banks (7.2 percent) is lower compared to lower middle income or Europe/Central Asia economies (29 and 39 percent, respectively, for access to bank loans, and 13 percent for both comparator groups for bank-financed investment) (Figure 1). The percent of small firms with a bank loan or credit line is less than half compared to their large firm peers, and the proportion of investment small firms finance via banks is also less than half that their large firm peers. Firms operating in manufacturing appear to have better access to bank loans, while differences for firms' access to a bank loan in various regions of the Kyrgyz Republic are very small. More broadly, financial sector deepening indicators such as private banking credit to GDP is well below Georgia or Armenia, Emerging Europe, and emerging market and developing economies (EMs) while the cost of finance is much higher (Figure 2).

Interest rate spreads and collateral requirements in the Kyrgyz Republic are relatively high from both a regional and global perspective. Macroeconomic stability and strengthened supervision could have brought new banking entrants, increased competition and reduced spreads. But although they have moderated relative to the 2000 s and more recently since 2008 , interest rate spreads still remain high (10 percentage points, the second highest in the CCA after Tajikistan and among the highest in the world) and have not declined as much as expected given the country's fundamentals and progress in banking supervision (Figure 2, Table 1). They most likely constrain financial intermediation and hamper the effectiveness of the credit channel for monetary policy transmission. At the same time, internal policies of banks on collateral appear to be onerous. The proportion of loans requiring collateral ( 93.6 percent) and the collateral needed (244 percent of loan amount) are higher than the average in EMs overall or in Emerging Europe (Figure 2), and they have become more stringent since 2013 when the proportion of loans requiring collateral and the collateral needed were lower ( 84.7 and 194 percent of loan amount). While high interest rate spreads can indicate a lack of competition and efficiency, high

\footnotetext{
${ }^{1}$ Acknowledgements: I am grateful to Nicolas Blancher, SubirLall, Christian Josz, and Ebru Sonbul Iskender for insightfulcomments provided on the paper, to the NationalBank of the Kyrgyz Republic for providing key statistical data and the suggestions received, as well as the numerous discussions with commercial banks.
} 
collateral requirements could stem from weaknesses in the rule of law and illiquid and volatile property markets and their impact is to ration credit supply. ${ }^{2}$

The banking system in the Kyrgyz Republic compares favorably with its regional peers in terms of financial soundness, but there is room to strengthen efficiency and competition as well as the rule of law and the availability of credit information (Figure 2). Capital ratios are high and deposit-to-loan ratios are near 100 percent, implying that deposits are being mostly transformed into loans (aside of what banks hold as reserve requirements). The levels of nonperforming loans are relatively low (even though restructured loans are higher) and well provisioned for. Dollarization levels of both assets and liabilities have come down significantly over the past few years. However, profitability ratios are lower than in some of the regional peers. Efficiency indicators suggest that noninterest costs are higher compared to peers (67 percent of financial income) and personnel costs take up more than half of noninterest costs. At the same time, three-largest banks concentration is higher than in some of the regional peers and the Herfindahl-Hirschman bank concentration index (HHI) points towards increasing concentration since 2016. From discussions with banks, the cost of external financing of basic loan operations appears to be high, especially for smaller banks, while the deposit base is low and the maturity short. The weaknesses of the legal framework and especially the depth of credit information and credit bureau coverage is lower compared to some regional peers (see Section $\mathrm{V})$.

The pandemic and health and containment measures, alongside a large external shock due to a fall in remittances and tourist receipts, greatly disrupted economic activity. The disruption to corporates' cashflows and household incomes may have heightened the fragility of the banking system. Authorities reacted to the pandemic with supportive fiscal, monetary and financial sector policies, to cushion the impact of the crisis on the real economy and preserve financial stability. Responses included liquidity provisions by the central bank to support the interbank market and loosening of macroprudential policies and regulatory responses aimed at helping the banking system to absorb stresses and support the provision of vital credit to the economy. Supervisory forbearance was also put in place, including to avoid an excessively procyclical impact on credit and provisioning. Specific measures to support businesses/SMEs included some tax relief and exemptions from rent payments, and a moratorium on debt repayments and extended provision of loan guarantees for SMEs. Further, the government has provided $\$ 133$ million (1.8 percent of GDP) to the banking sector for additional lending (soft loans) to businesses/SMEs. A swift response was indeed essential to preserve macro-financial stability, but these policies need to be calibrated and timed carefully to minimize moral hazard and avoid creating lasting distortions in the financial sector, and liabilities for the public sector.

\footnotetext{
${ }^{2}$ A majority of loa ns are offered at maturities of 1-3 years. Loan maturity appears to be moving in the same direction as spreads for maturities up to $6 \mathrm{mon}$ ths, while sprea ds are decreasing for maturities above one year, at which point colla teral requirements becomem ore stringent to compensate for risk.
} 
This paper takes closer look at the determinants of interest rate spreads and the collateral policies applied by banks in the Kyrgyz Republic to inform policymakers on potential reforms needed in the aftermath of the pandemic. The paper proceeds as follows: the next section presents a brief literature review. Section III lays out three methodologies for examining the source of the Kyrgyz Republic's effective interest rate spreads. Section IV is dedicated to presenting the results of the analysis using these methodologies. Section V analyzes the collateral policies applied by banks. The last section highlights what policies are needed to lower intermediation costs, ease collateral requirements, and support a deepening of the financial system. 
Figure 1. Kyrgyz Republic: Access to Finance, 2019

Use of Financial Services

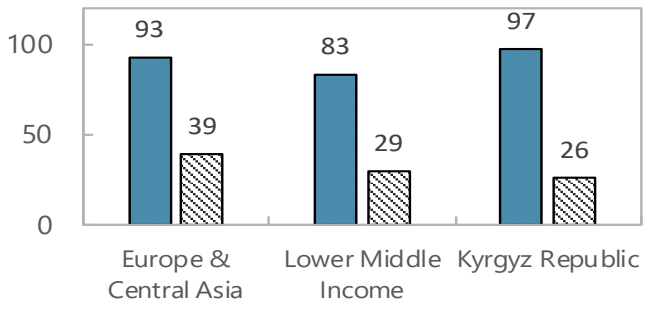

$\square$ Percent of firms with a checking or savings account

$\square$ Percent of firms with a bank loan/line of credit

Use of Financial Services

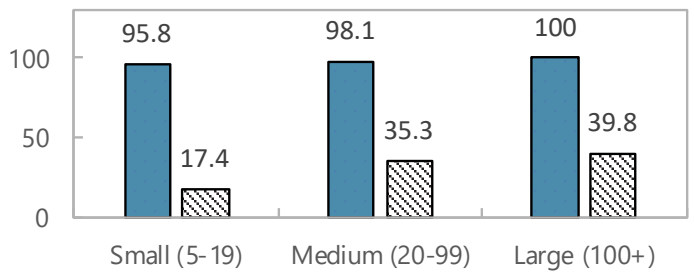

$\square$ Percent of firms with a checking or savings account

$\square$ Percent of firms with a bank loan/line of credit

Use of Financial Services

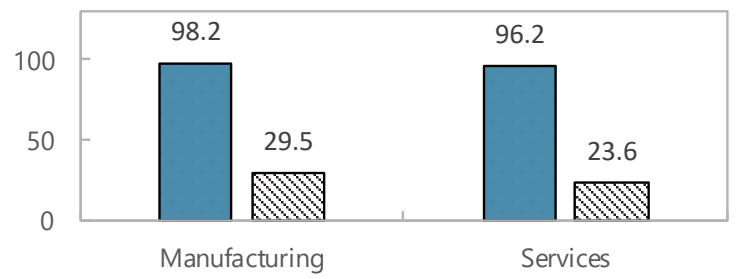

$\square$ Percent of firms with a checking or savings account

$\square$ Percent of firms with a bank loan/line of credit

Use of Financial Services

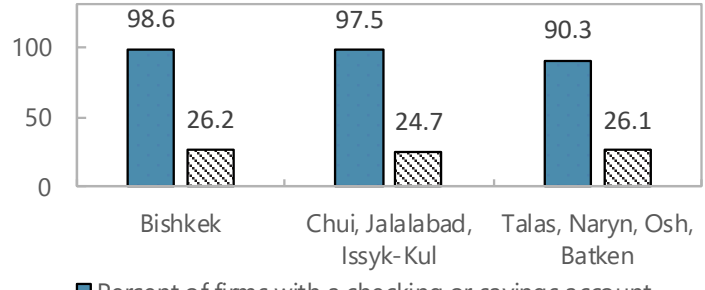

$\square$ Percent of firms with a checking or savings account

$\square$ Percent of firms with a bank loan/line of credit

\section{Sources of financing for purchase of fixed assets}

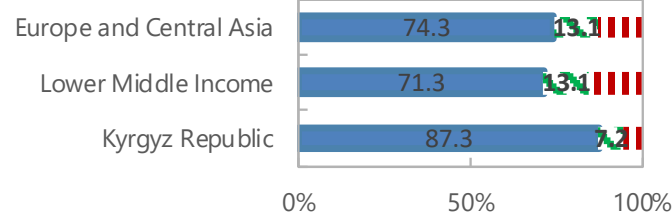

Proportion of investment financed internally (\%) Proportion of investment financed by banks (\%) Other

Sources of financing for purchase of fixed assets

Large $(100+)$

Medium (20-99)

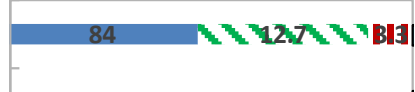

Small (5-19)

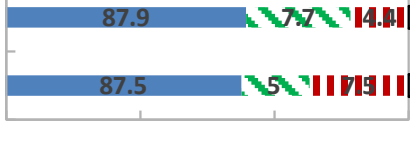

$\begin{array}{llll}70 & 80 & 90 & 100\end{array}$

- Proportion of investment financed internally (\%) Proportion of investment financed by banks (\%) Other

Sources of financing for purchase of fixed assets

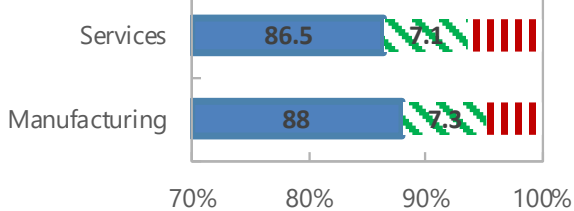

Proportion of investment financed internally (\%) Proportion of investment financed by banks (\%) Other

Sources of financing for purchase of fixed assets

Talas, Naryn, Osh, Batken

Chui, Jalalabad, Issyk-Kul Bishkek

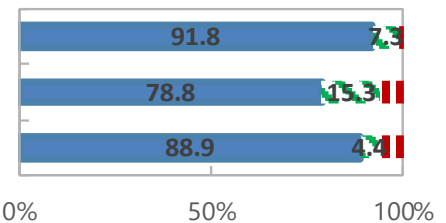

Proportion of investment financed internally (\%) Proportion of investment financed by banks (\%) Other 


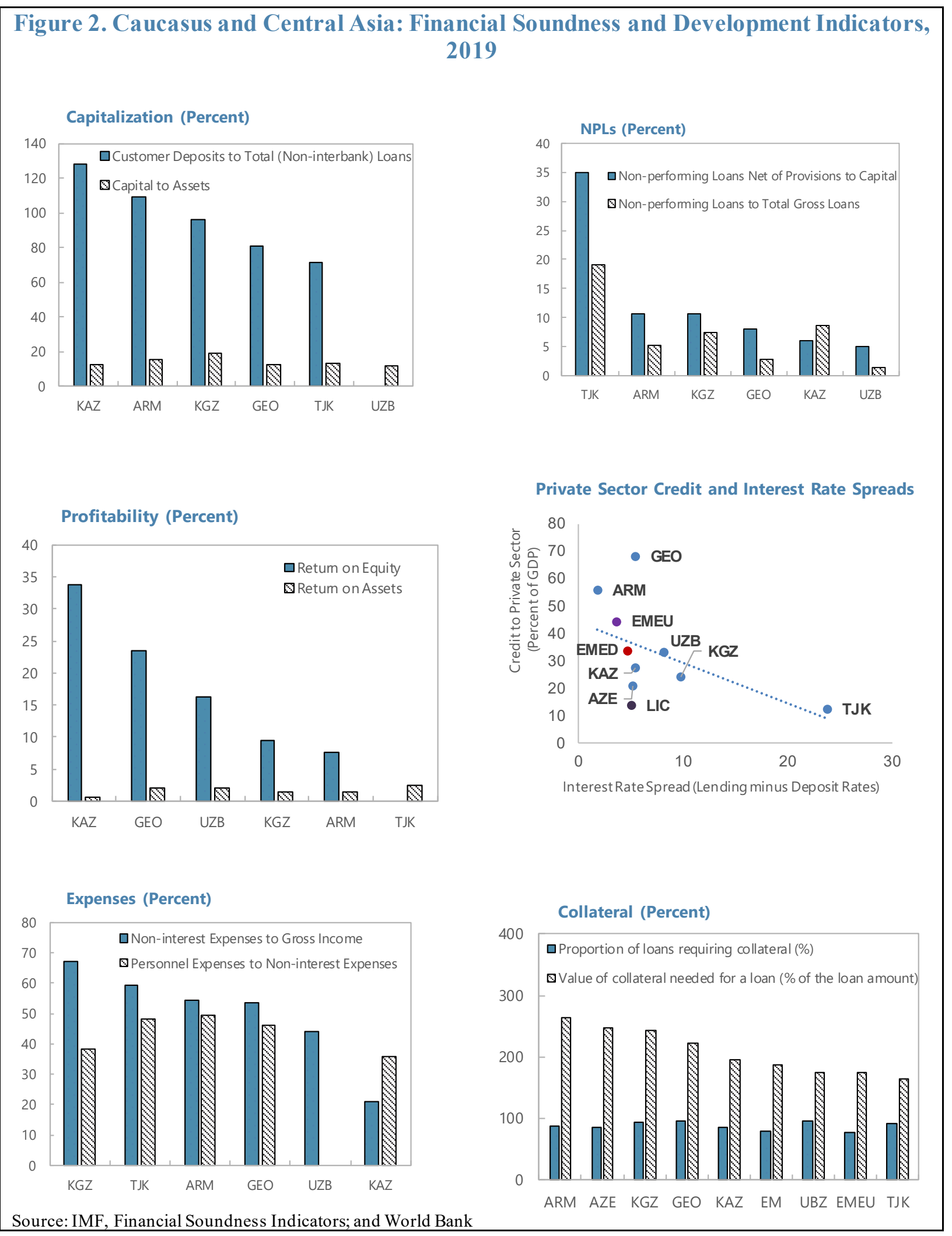




\section{Literature REVIEW}

\section{The extensive literature on the likely determinants of the cost of financial intermediation and collateral policies emphasizes the following factors:}

- Bank-specific factors such as managerial capabilities, overhead costs, bank size, risk assessment capacity, and investment management, influence banking efficiency (DemirgüçKunt and Huizinga, 1999; Dell'Arriccia and Márquez, 2004). At the same time, the market structure within which banks operate (ownership structure, market concentration, competition) can have important implications for the incentives of banks to overcome market frictions and efficiently intermediate the economy's savings to borrowers. DablaNorris and Floerkemeier (2007) find that bank-specific factors, such as bank size, liquidity, and market power, as well as the market structure within which banks operate, explain a large proportion of cross-bank, cross-time variation in spreads and margins in Armenia. In Latin America, Gelos (2009), the correlation between bank-level measures of administrative and personnel costs - an indicator of competitive pressures - and interest margins is strong, suggesting the presence of substantial inefficiencies. A recent study on Central Asia (Almarzoqi and Naceur, 2015) found that operational efficiency is by far the most important driver of interest spreads. The authors also find that higher market power increases interest rate spreads in some countries in Central Asia. The study by Ross and Peschiera (2015) suggests that increases in system-wide concentration levels did indeed raise spreads in Peru; however, banks that gained market share ended up lowering effective spreads, implying competitive behavior.

- Taxation, including reserve requirements, drives a wedge between borrowing and lending rates. Gelos (2009) finds that reserve requirements on demand deposits are strongly correlated with intermediation spreads in Latin America. Almarzoqi and Naceur (2015) also show that lowering reserve requirements is likely to reduce the cost of intermediation in Central Asia.

- Creditor rights and the legal/institutional framework contribute to the efficiency of intermediation through its impact on loan recovery rates, enforceability of foreclosures, and collateral collection, as well as market transparency and information sharing on borrowers (Demirgüç-Kunt and others, 2004). Gelos (2009) shows a clear negative correlation between net interest margins and the legal system and property rights in Latin America. In East Africa, M. Cihak and R. Podpiera (2006) emphasize that resolving weak banks or closing them and improving the legal framework for property rights, insolvency, and creditor rights is critical to strengthen banking efficiency and reduce spreads. The introduction of a credit registry and the establishment of a private credit bureau have been important steps towards improving information sharing on the creditworthiness of borrowers in Armenia (DablaNorris and Floerkemeier, 2007). Improving corporate accounting and disclosure remains a prerequisite for reaping the full benefits of information sharing, attaining financial deepening, and lowering the cost of financial intermediation (Levine and others, 2000). 
- Macroeconomic volatility may raise the risk of default and therefore bank spreads. In the dealership model of banks developed by Ho and Saunders (1981), interest margins rise with the variance of interest rates as a result of the intermediation risk faced by banks. This is supported empirically by Saunders and Schumacher (2000). Various studies find a positive correlation between spreads and inflation (Honohan 2003). Almarzoqi and Naceur (2015) find that the macroeconomic environment in Central Asia - proxied by the inflation rate and the policy rate-has a significant impact on interest margins, though the extent of the impact differs from country to country.

This paper contributes to the literature on the determinants of interest rate spreads and margins in low-income economies. Most studies on the determinants of the cost of financial intermediation have focused on emerging markets and transition economies in Central and Eastern Europe, while there is scant or no empirical evidence on the drivers of banking sector spreads in low-income economies such as the Kyrgyz Republic.

\section{MeThodology}

\section{The paper examines the source of the Kyrgyz Republic's effective interest rate spreads through accounting decompositions, financial ratio analysis, and spread regressions.}

- Banks play an important intermediation role by transforming customer deposits into loans. While interest rate spreads reflect this risk-taking role, their level and evolution also contain information regarding regulation and operating costs as well as management decisions - all of which can be evaluated by accounting decompositions. Using balance sheet and income statement data, the effective interest rate spreads can be decomposed into the following components:

$(i l-i l i a b)=r r+o c+p r o v+p$

where $i l$ is the average effective interest rate charged on loans, iliab is the average effective interest rate provided on interest-bearing liabilities, $r r$ is the required reserves/liabilities, $o c$ is the overhead costs/loans, prov is the provisions/loans, and $p$ is the pre-tax profit margin, calculated as the residual. This equation captures the most important factors that determine effective interest rate spreads, as in Cihak and Podpiero (2005), Ross and Peschiera (2015), or Alper et al (2019).

- Viewed from a slightly different angle, banks make profits through the use of leverage and an efficient deployment of their assets and operations. In this context, an examination of financial ratios focused on profit creation provides a complementary view to interest rate spread decomposition. Financial statement analysis focuses on three key financial ratios: 
return on equity (RoE), return on assets (RoA), and net interest margin (NIM), each of which can be further decomposed:

- RoE is the ratio between after tax earnings (EAT) and book value of equity (BE). It presents the earnings per unit of invested capital, measuring the profitability of investment. RoE consists of three components: (1) tax policy $(T P=E A T / E B T$ (earnings before tax)), (2) financial leverage $(L E V=T A$ (total assets)/BE), and (3) $\operatorname{RoA}(\operatorname{Ro} A=E B T / T A)$.

$R O E=T P \times L E V \times R O A$

- A bank's RoA can be further disaggregated into three components: (1) burden (B $=\mathrm{NNIR}$ (net noninterest revenues)/TA), (2) earning assets ratio $(E A R=E A$ (earning assets)/TA), and (3) net interest margin NIM $(N I M=(I R$ (interest revenue) - IE (interest expense))/EA). Burden measures the success in maintaining control over operating costs. Earning asset ratios are a good indicator for analyzing the strategic focus of individual banks. The NIM reveals the net income from investing through borrowed funds.

$$
R o A=B+E A R \times N I M
$$

- Finally, the NIM can also be decomposed into three variables: (1) return on earning assets $(R E A=I R / E A),(2)$ cost of liabilities $(C O L=I E / L)$, and (3) liabilities to earning assets $(L E A=L / E A)$. The return on earning assets directly connects earning assets and interest revenue, measuring the average rate of lent funds. $C O L$ is an indicator of the average price of borrowed capital, while $L E A$ measures the intensity of the bank's investment activities.

$$
N I M=R E A-C O L \times L E A
$$

- Finally, regressions of interest rate spreads (or net interest margins) on potential explanatory variables offer a direct way to estimate the influence of risk, costs, and market power. The estimation of the regressions follows the framework of Gelos (2009), Ross and Peschiera (2015), and Almarzoqi and Naceur (2015), in which the theoretical motivated drivers of spreads and net interest margins comprise bank competition, operating costs, credit risk, and loan size, as well as institutional variables such as the strength of the legal framework (e.g., protection of property rights, contract enforcement) and the availability of credit information. Additional macroeconomic conditioning variables - the three-month LIBOR, domestic inflation, and the exchange rate - are also included. Using monthly timeseries data (December 2005 to December 2018), we estimated the following equations: 


$$
\begin{aligned}
& \text { Spread }_{t}=\alpha+\beta_{1} K A_{t}+\beta_{2} \text { Size }_{t}+\beta_{3} \text { Loan loss prov }_{t}+\beta_{4} \text { Deposit rate }_{i t}+ \\
& \beta_{5} \text { Cost }_{t}+\beta_{6} \mathrm{HHI}_{t}+\beta_{7} G_{t}+\beta_{8} \text { Inf }_{t}+\beta_{9} E R_{t}+\beta_{10} \text { Libor }_{t}+e_{t} \text { (1) } \\
& \text { Spread }_{t}=\alpha+\beta_{1} K A_{t}+\beta_{2} \text { Size }_{t}+\beta_{3} \text { Loan loss prov }_{t}+\beta_{4} \text { Deposit rate }_{i t}+ \\
& \beta_{5} \text { Cost }_{t}+\beta_{6} \text { HHI }_{t}+\beta_{7} \text { Cost }_{t} \text { HHI }_{t}+\beta_{8} G_{t}+\beta_{9} \text { Inf }_{t}+\beta_{10} \text { ER }_{t}+\beta_{11} \text { Libor }_{t}+e_{t} \text { (2) } \\
& \text { Spread }_{t}=\alpha+\beta_{1} \text { KA }_{t}+\beta_{2} \text { Size }_{t}+\beta_{3} \text { Loan loss prov } t+\beta_{4} \text { Cost }_{t}+\beta_{5} \mathrm{HHI}_{t}+ \\
& \beta_{6} \operatorname{Cost}_{t} \mathrm{HHI}_{t}+\beta_{7} G_{t}+\beta_{8} \text { Inf }_{t}+\beta_{9} E R_{t}+\beta_{10} \text { Libor }_{t}+e_{t} \text { (3) } \\
& \text { Spread }_{t}=\alpha+\beta_{1} \text { Size }_{t}+\beta_{2} N P L s_{t}+\beta_{3} \text { Cost }_{t}+\beta_{4} \text { HHI }_{t}+\beta_{5} \text { Cost }_{t} \text { HHI }_{t}+\beta_{6} G_{t}+ \\
& \beta_{7} \operatorname{Inf}_{t}+\beta_{8} E R_{t}+\beta_{9} \text { Libor }_{t}+e_{t}(4) \\
& \text { Spread }_{t}=\alpha+\beta_{1} K_{t}+\beta_{2} \text { Size }_{t}+\beta_{3} N P L s_{t}+\beta_{4} \text { Deposit rate }_{i t}+\beta_{5} \text { Cost }_{t}+ \\
& \beta_{6} \mathrm{HHI}_{t}+\beta_{7} \text { Cost }_{t} \mathrm{HHI}_{t}+\beta_{8} G_{t}+\beta_{9} \text { Inf }_{t}+\beta_{10} \text { ER }_{t}+\beta_{11} \text { Libor }_{t}+\beta_{12} \text { Legal }_{t}+e_{t}
\end{aligned}
$$

The dependent variable is the effective interest rate spread (Spread: difference between weighted averages of lending rates and bank funding costs) or net interest margins for equations (3) (NIM: banks' total interest income minus total interest expense, divided by the sum of interest-bearing assets). The main explanatory variables reflect capital (Kapital), operating costs (Cost), loan size (Size), non-performing loans (NPLs) or loan loss provisioning (Loan loss prov), deposit rates (Deposit rate), as well as the Herfindahl Hirschman Index $(H H I)$ - a measure of market concentration calculated as the sum of squared market shares of individual banks; it ranges from $1 / n$ to one and tends to zero as the market approaches perfect competition. An institutional composite variable - Legal System and Property Rights index, comprising judicial independence, protection of property rights, integrity of legal system, enforcement of contracts, among others, from the Economic Freedom Index of the World Annual Reports, is also used given the expected importance of institutional factors in determining spreads; each sub-component of the index is placed on a scale from 0 to 10 that reflects the distribution of the underlying data across countries, with a rating of 10 for the strongest legal system. Additional macroeconomic conditioning variables - the three-month Lond on interbank offered rate (LIBOR), economic growth $(G)$, domestic inflation (Inf), and the KGS-U.S. dollar exchange rate (ER) - are also included.

\section{ReSUlts}

\section{System-wide accounting interest rate spread decompositions from 2006-18 show that} spreads decreased over time with a reduction in profit margins (Table 1). Interest rate spreads were high during the global financial crisis (GFC) and increased again during the external shocks of 2015-16, but they appear to be on a declining trend. Lending rates follow the same pattern. However, at 14.2 percent in 2018 , they still remain high. The decrease in spreads over time is explained by the gradual decline in pre-tax profits to 2.3 percent in 2018 (from 9 percent during the GFC), likely due to higher competition. Operating costs are the main factor 
behind the still high interest rate spreads. They have remained around 6.4 percent (the average over 2006-18) and have only slightly declined since the GFC. The costs of loans loss provisions have increased since 2015-16 and are 1.1 percent in 2018, while the costs of covering required reserves are small across banks.

\begin{tabular}{|c|c|c|c|c|c|c|c|c|c|c|c|c|c|}
\hline & 2006 & 2007 & 2008 & 2009 & 2010 & 2011 & 2012 & 2013 & 2014 & 2015 & 2016 & 2017 & 2018 \\
\hline Interest earned on loans & 18.4 & 16.0 & 20.0 & 21.8 & 19.4 & 18.2 & 18.7 & 16.7 & 15.4 & 18.8 & 19.7 & 16.4 & 14.2 \\
\hline Interest paid on interest bearing liabilities & 2.8 & 3.6 & 4.9 & 4.4 & 3.4 & 4.0 & 4.4 & 4.1 & 4.9 & 6.4 & 6.9 & 5.0 & 4.4 \\
\hline Spread & 15.6 & 12.4 & 15.0 & 17.4 & 16.0 & 14.3 & 14.3 & 12.5 & 10.5 & 12.4 & 12.8 & 11.3 & 9.8 \\
\hline Operating costs/loans & 6.2 & 5.7 & 7.0 & 6.4 & 6.8 & 7.6 & 7.1 & 6.2 & 6.1 & 5.9 & 6.3 & 6.4 & 6.1 \\
\hline Loan loss provisions/loans & 1.6 & 0.8 & 1.7 & 1.6 & 2.9 & -0.3 & 0.0 & 0.8 & 0.7 & 1.6 & 1.6 & 0.6 & 1.1 \\
\hline Interest paid to cover required reserves & 0.3 & 0.4 & 0.5 & 0.4 & 0.3 & 0.4 & 0.4 & 0.4 & 0.4 & 0.5 & 0.5 & 0.4 & 0.3 \\
\hline Pre-tax profit & 7.5 & 5.5 & 5.8 & 9.0 & 6.1 & 6.7 & 6.8 & 5.2 & 3.3 & 4.5 & 4.3 & 4.0 & 2.3 \\
\hline
\end{tabular}

Sources: NBKR, and IMF staff calculations.

Interest rate spread decompositions across various bank subgroupings in 2018 (i.e., 5 largest banks, 10 medium-sized banks, and 10 smallest banks) reveal that spreads are much higher for medium-sized and small banks (Table 1a). Operating costs are the main contributor to these higher spreads for medium-sized and small banks (8-8.5 percent compared to 4.5 percent for the largest banks). Pretax profits also appear to be very high for the smallest banks.

Financial statement analysis finds that RoE has been decreasing

\begin{tabular}{lrrr}
\hline Table 1a. Contribution to Interest Rate Spreads (In Percent), 2018 & \\
\hline & $\begin{array}{r}\text { Largest } \\
\text { Banks }\end{array}$ & $\begin{array}{c}\text { 10 Medium- } \\
\text { Sized Banks }\end{array}$ & $\begin{array}{c}\text { 10 Small } \\
\text { Banks }\end{array}$ \\
\hline Interest earned on loans & 9.6 & 17.7 & 35.0 \\
Interest paid on interest bearing liabilities & 3.5 & 6.2 & 4.4 \\
Spread & $\mathbf{6 . 2}$ & $\mathbf{1 1 . 5}$ & $\mathbf{3 0 . 6}$ \\
Operating costs/loans & 4.5 & 8.5 & 8.0 \\
Loan loss provisions/loans & 1.9 & 0.0 & 0.0 \\
Interest paid to cover required reserves & 0.3 & 0.5 & 0.3 \\
Pre-tax profit (residual) & -0.5 & 2.5 & 22.2 \\
\hline
\end{tabular}
steadily, mainly due to lower RoA, Sources: NBKR, and IMF staff calculations.

given a higher burden from administrative costs (Table 2). RoE has steadily decreased since its peak in 2011-14 (15 percent, on average) to 9 percent in 2018-lower than in Kazakhstan, Georgia, and Uzbekistan. It was relatively high before the bankruptcy of AUB in 2010, when it halved, and recovered thereafter before falling again during the large external shocks of 201516. Tax policy effects have remained stable over 2006-18 and have not been a big drag on profits. At the same time, the RoA has fallen slightly since 2014 , while the main driver of banking sector profitability since the GFC has been an increase in leverage. The burden from administrative costs has contributed to the fall in the RoA over the past few years. The burden has negative values, since noninterest revenues are not able to cover all administrative and noninterest expenses. The NIMs have fallen slightly in the past few years due to lower return on earning assets offset by lower cost of liabilities and minor improvement in investment intensity. 


\begin{tabular}{|c|c|c|c|c|c|c|c|c|c|c|c|c|c|}
\hline & 2006 & 2007 & 2008 & 2009 & 2010 & 2011 & 2012 & 2013 & 2014 & 2015 & 2016 & 2017 & 2018 \\
\hline ROE $=T P \times$ LEV $\times$ ROA & 0.17 & 0.17 & 0.15 & 0.12 & 0.07 & 0.15 & 0.16 & 0.13 & 0.16 & 0.09 & 0.03 & 0.07 & 0.09 \\
\hline Tax Policy (EAT / EBT) & 0.89 & 0.90 & 0.90 & 0.89 & 0.84 & 0.89 & 0.88 & 0.89 & 0.89 & 0.88 & 0.82 & 0.86 & 0.87 \\
\hline Financial Leverage (TA/E) & 6.05 & 5.00 & 4.70 & 4.98 & 5.12 & 5.06 & 5.58 & 6.07 & 6.61 & 6.86 & 6.28 & 6.13 & 6.31 \\
\hline Return on Assets (EBT / TA) & 0.03 & 0.04 & 0.04 & 0.03 & 0.02 & 0.03 & 0.03 & 0.02 & 0.03 & 0.01 & 0.01 & 0.01 & 0.02 \\
\hline $\mathrm{ROA}=\mathrm{NNIR} / \mathrm{TA}+\mathrm{EA} / \mathrm{TA} \times \mathrm{NIR} / \mathrm{EA}$ & 0.03 & 0.04 & 0.04 & 0.03 & 0.02 & 0.03 & 0.03 & 0.02 & 0.03 & 0.01 & 0.01 & 0.01 & 0.02 \\
\hline Burden (NIR-NIE / TA) & -0.02 & -0.02 & -0.02 & -0.02 & -0.04 & -0.02 & -0.02 & -0.03 & -0.03 & -0.04 & -0.05 & -0.04 & -0.04 \\
\hline Earnings to Assets (EA/TA) & 0.47 & 0.60 & 0.57 & 0.48 & 0.49 & 0.52 & 0.54 & 0.56 & 0.62 & 0.55 & 0.57 & 0.61 & 0.67 \\
\hline $\mathrm{NIM}(\mathrm{IR}-\mathrm{IE} / \mathrm{EA})$ & 0.12 & 0.09 & 0.10 & 0.10 & 0.12 & 0.10 & 0.10 & 0.09 & 0.09 & 0.10 & 0.09 & 0.08 & 0.08 \\
\hline NIM $=$ REA - COL $x$ LEA & 0.12 & 0.09 & 0.10 & 0.10 & 0.12 & 0.10 & 0.10 & 0.09 & 0.09 & 0.10 & 0.09 & 0.08 & 0.08 \\
\hline Return on earning assets (IR / EA) & 0.16 & 0.13 & 0.16 & 0.16 & 0.16 & 0.15 & 0.15 & 0.14 & 0.14 & 0.18 & 0.17 & 0.14 & 0.12 \\
\hline Cost of Liabilities (IE/L) & 0.02 & 0.03 & 0.05 & 0.04 & 0.03 & 0.03 & 0.04 & 0.03 & 0.04 & 0.05 & 0.06 & 0.04 & 0.04 \\
\hline Liabilities to Earning Assets (L / EA) & 1.76 & 1.30 & 1.35 & 1.64 & 1.58 & 1.50 & 1.49 & 1.45 & 1.34 & 1.51 & 1.43 & 1.34 & 1.22 \\
\hline
\end{tabular}

Source: IMF staffestimates.

Note: $\mathrm{COL}=$ cost of liabilities; $E=$ earnings; $E A=$ earning assets; $E A T=$ earnings after tax; $E B T=$ earnings before tax; $I E=$ interest expense; $I R=i n t e r e s t$ revenue; $L=$ liabilities; LEA = liabilities to earning assets; LEV = financial leverage; NIE = noninterest expenses; NIM = net interest margin; NIR = noninterest revenues; NNIR = net noninterest revenues; $\mathrm{REA}=$ return on earning assets; $\mathrm{ROA}=$ return on assets; $\mathrm{TA}=$ total assets; $\mathrm{TP}=$ tax policy.

\section{The regression analysis identifies the following main robust, statistically significant determinants of interest rate spreads (Table 3):}

- An increase in capital ratios (Kapital) is significantly related to a reduction in spreads (by 0.14 percentage points). This suggests that high capital ratios may be an indication that wellcapitalized banks charge lower spreads for their lower risk of bankruptcy and greater stability (similar to what was found in the Caucasus and Central Asia (Almarzoqi et al, 2015), in Armenia (Dabla-Norris et al, 2007) and the Czech Republic (Horvath, 2009)).

- An increase in competition in the banking sector is

\begin{tabular}{|c|c|c|c|c|c|c|}
\hline \multirow[b]{2}{*}{ Kapital } & \multicolumn{5}{|c|}{ Spread } & \multirow{2}{*}{$\frac{N I M}{-0.16 * * *}$} \\
\hline & $-0.15 * * *$ & $-0.14 * *$ & $-0.15 * * *$ & & $-0.18 * *$ & \\
\hline$(\mathrm{t})$ & -2.71 & -2.49 & -2.69 & & -2.52 & -3.08 \\
\hline Loan Size & $-0.18 * * *$ & $-0.20 * * *$ & $-0.16^{* * *}$ & $-0.09 * *$ & $-0.34 * * *$ & $-0.14 * * *$ \\
\hline$(\mathrm{t})$ & -3.90 & -4.34 & -3.64 & -2.02 & -4.21 & -3.65 \\
\hline Loan Loss Prov (1) / NPLs (2) & $0.07^{* * *}(1)$ & $0.05 * *(1)$ & $0.04 *(1)$ & $0.10^{* *}(2)$ & $-0.03(2)$ & $0.02(1)$ \\
\hline$(\mathrm{t})$ & 2.90 & 2.10 & 1.73 & 2.31 & -0.53 & 0.70 \\
\hline Deposit Rate & $0.64 * *$ & $0.57^{* *}$ & & & $0.69 * * *$ & \\
\hline$(\mathrm{t})$ & 2.59 & 2.31 & & & 2.64 & \\
\hline Cost & 0.01 & $0.39 * *$ & $0.46 * *$ & $0.48^{* *}$ & $0.42 *$ & $0.31 *$ \\
\hline$(\mathrm{t})$ & 0.46 & 2.03 & 2.40 & 2.41 & 1.95 & 1.82 \\
\hline $\mathrm{HHI}$ & $0.64 * * *$ & $3.52 * *$ & $3.86 * * *$ & $4.44 * * *$ & $3.34 * *$ & $2.86 * *$ \\
\hline$(\mathrm{t})$ & 4.67 & 2.44 & 2.63 & 3.06 & 2.13 & 2.18 \\
\hline $\mathrm{HHI}$ Cost & & $-4.01 * *$ & $-4.68 * *$ & $-5.25 * * *$ & $-4.06 *$ & $-3.25 *$ \\
\hline$(\mathrm{t})$ & & -2.01 & -2.32 & -2.60 & -1.87 & -1.80 \\
\hline GDP Growth & $-0.02 * *$ & $-0.03 * *$ & $-0.03 * * *$ & $-0.03 * * *$ & $-0.03 * *$ & $-0.03 * * *$ \\
\hline$(\mathrm{t})$ & -2.18 & -2.36 & -2.67 & -2.40 & -2.51 & -2.63 \\
\hline Inflation & $0.05 * * *$ & $0.05 * * *$ & $0.04 * * *$ & $0.03 * *$ & $0.07 * * *$ & $0.05 * * *$ \\
\hline$(\mathrm{t})$ & 4.05 & 3.82 & 3.25 & 2.29 & 3.77 & 4.46 \\
\hline REER & $-0.08 * * *$ & $-0.08 * * *$ & $-0.06 * *$ & $-0.05 *$ & $-0.08 * *$ & $-0.06 * * *$ \\
\hline$(\mathrm{t})$ & -3.05 & -3.34 & -2.64 & -1.76 & -2.27 & -3.00 \\
\hline Libor & $0.35 * * *$ & $0.40 * * *$ & $0.25 * *$ & 0.03 & 0.52 & $0.28 * * *$ \\
\hline$(\mathrm{t})$ & 2.73 & 3.10 & 2.18 & 0.21 & 1.62 & 2.75 \\
\hline Legal/Property Rights & & & & & $-4.57 *$ & \\
\hline$(\mathrm{t})$ & & & & & -1.84 & \\
\hline Obs & 121 & 121 & 121 & 121 & 109 & 121 \\
\hline$R^{2}$ & 0.72 & 0.72 & 0.72 & 0.71 & 0.75 & 0.70 \\
\hline Prob (F) & 0.0 & 0.0 & 0.0 & 0.0 & 0.0 & 0.0 \\
\hline
\end{tabular}

Source: IMF staff calculations.

Note: t-statistics are below the estimated coefficients. * significant at $10 \%$;

** significant at $5 \%$; *** significant at $1 \%$. 
associated with lower spreads for a certain level of costs, captured by an interaction term between $H H I$ and Costs. I.e. if operating costs are 50 percent of financial income, a reduction in the $H H I$ from the current level of competition of 9 to 8 percent would lead to a fall in spreads by 1.5 percentage points. Higher competition would pressure banks to lower spreads for a certain level of costs, i.e. even if banks had lower costs but there was no pressure from competition, spreads would remain high (as profits would remain high).

- Spreads could be reduced as the loan size (Loan Size), measured as loans to GDP, increases (by 0.20 percentage points). This measure is most likely a reflection of the creditworthiness of borrowers, i.e. banks extend larger loans to more creditworthy clients. Also, NPLs (to total loans) or loan loss provisioning are positively and significantly associated with spreads. This is likely a reflection of credit risk with weaker asset quality giving rise to a need to make up past losses by charging higher lending rates and raising spreads.

- A higher level of interest rates (i.e. Deposit Rate) is associated with higher spreads (by 0.57 percentage points), likely because banks can charge higher lending rates in the context of imperfect competition (similar to what was found in Latin America (Gelos, 2009). ${ }^{1}$ While there is no data on banks' credit default swaps for the Kyrgyz Republic, external funding costs are likely to be positively and significantly associated with spreads. ${ }^{2}$

- A more supportive legal environment (i.e. Legal System/Property Rights) is associated with lower spreads, likely reflecting the importance of a strong institutional and legal framework in supporting higher recovery rates and in reducing delays for collateral repossession (similar to what was found in Latin America (Gelos, 2009)).

\section{Constraints to Collateral ${ }^{3}$}

The NBKR sets minimum prudential requirements for collateral. The Regulation on assets classification requires that loans be covered by collateral of at least 120 percent of the loan amount to be classified as 'normal' assets in terms of risk level. Further, there are limits on uncollaterized (unsecured) loans which stipulate that uncollateralized loans should not exceed 50 percent of a bank's net total capital. While these are the minimum collateral requirements with which banks need to comply, their internal policies could be much more stringent.

Banks make a case-by-case determination on collateralized loans. Depending on the type of collateral offered, as well as the region in which the firm borrows, discount rates (from market values) are applied to the collateral value which can range from 50 percent to 90 percent. For

\footnotetext{
${ }^{1}$ A possible objection to including the deposit rates is that it is endogenous since it is jointly chosen with lending ra tes by banks. When we include instead interbank rates, they are insignificant, while T-Bill rates are negatively a ssociated with spreads.

${ }^{2}$ Discussions with the banking sector highlighted the importance of this factor for explaining the high spreads.

${ }^{3}$ Discussions with the banking sector inform this section on colla teral constraints.
} 
example, real estate in the capital which is relatively easy to sell will be discounted by 30 percent, while real estate in rural areas or factories which are more difficult to sell are discounted by 40 percent; and movables and stocks/equity by 50 percent. Furthermore, the borrower faces an additional burden as the collateral required most often surpasses 120 percent of loan amount. Banks also do not accept agricultural land as collateral given the restriction they face to own and sell it (they are required to sell it after two years first to the local individual/entity). This challenge is particularly acute for SMEs in agriculture, particularly in the south, which have assets in rural areas and thus face valuation issues. Around 40-50 percent of SMEs fail to obtain a bank loan due to prohibitively high collateral requirements. It appears that the proportion of loans requiring collateral is higher in manufacturing than it is in services, and higher in the regions of Chui, Jalalabad, and Issyk-Kul than it is in the capital and in other regions, and the value of collateral needed appears to be much higher in manufacturing and in all the regions except the capital.

\section{Collateral requirements for small loans or group loans may be less constraining, and} uncollateralized loans are also offered. For example, the collateral will be discounted only by 10 percent if the loan size is less than US\$100,000, or there are no collateral requirements for group loans (which have a cross-guarantee of payment). Some banks offer as much as 20 percent of their loan portfolio without requiring collateral and they are reaching the threshold of uncollateralized loans of 50 percent of a bank's net total capital, and thus such a limit constrains their ability to provide credit even if they found additional qualifying customers.

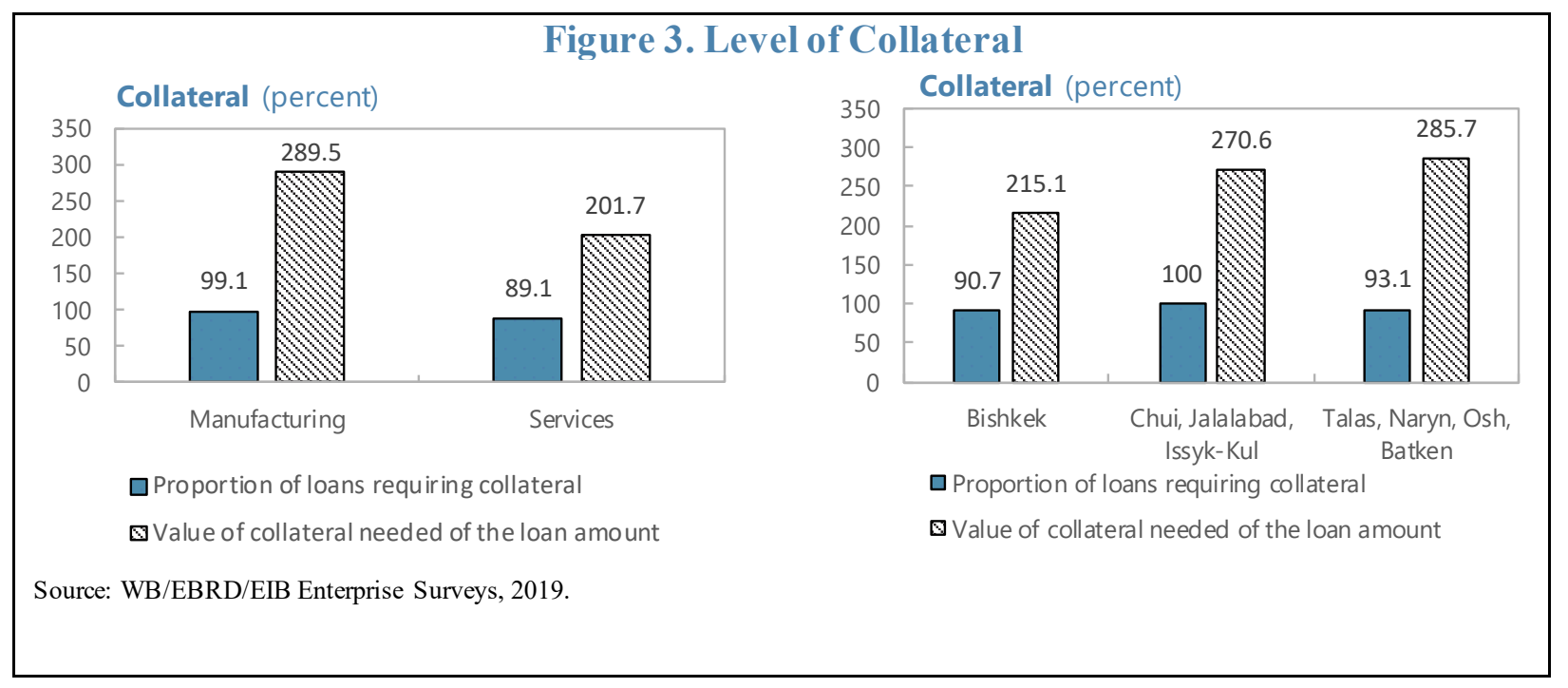


Banks cite information on SME creditworthiness, and collateral and legal risks as justification for their high collateral requirements. SMEs' credit worthiness is not easily available or sufficiently transparent to mitigate information asymmetries and might lead to high collateral requirements and credit rationing. Collateral risk - the risk that the collateral securing the loan will decline in value and be insufficient to liquidate the loan, or collateral illiquidity - the risk that the process to liquidate the collateral will be time-consuming and costly — are additional concerns expressed by banks with respect to collateral recovery. Banks used to seize collateral out of court through arbitration, but more recently, when the real estate used as collateral is the only property of the borrower, banks must follow court Quality of Legal Framework and Credit Information

\begin{tabular}{lcccc} 
& $\begin{array}{c}\text { Strength of } \\
\text { legal rights } \\
\text { index (0=weak } \\
\text { to 12=strong) }\end{array}$ & $\begin{array}{c}\text { Depth of credit } \\
\text { information } \\
\text { index (0=low } \\
\text { to 8=high) }\end{array}$ & $\begin{array}{c}\text { Private } \\
\text { credit bureau } \\
\text { coverage (\% } \\
\text { of adults) }\end{array}$ & $\begin{array}{c}\text { Rule of Law } \\
(-2.5=\text { weak } \\
\text { to } \\
\text { 2.5=strong) }\end{array}$ \\
\hline KAZ & 6 & 7 & 59.3 & -0.4 \\
GEO & 9 & 8 & 100 & 0.3 \\
UZB & 6 & 7 & 42.7 & -1.1 \\
KGZ & 9 & 6 & 37.9 & -0.9 \\
ARM & 6 & 8 & 80 & -0.2 \\
TJK & 1 & 7 & 44.9 & -1.3 \\
AZE & 8 & 8 & 41.5 & -0.6 \\
Average & 6.4 & $\mathbf{7 . 3}$ & $\mathbf{5 8 . 0}$ & $-\mathbf{0 . 6}$ \\
\hline
\end{tabular}
proceedings in three stages of appeal rather than go through arbitration, which prolongs the process of recovery.

\section{CONCLUSIONS AND RECOMMENDATIONS}

While a swift policy response was essential to preserve macro-financial stability and credit to the economy during the Covid pandemic, it is critical to avoid lasting distortions in the financial sector and liabilities for the public sector. Liquidity support should target solvent but illiquid firms and be time-bound. Eligibility criteria should be based on firms' creditworthiness prior to the crisis, in part to help mitigate procyclicality. The exit should be set by the maturity of lending to businesses and by the end of term funding provided by central banks for the issuance of new loans. Credit guarantees should only last until when loans under the scheme mature. The exit dates should be made clear upfront to prevent subsequent political pressures to prolong these schemes that are designed to provide liquidity support only during this crisis. Any moratoria on loan repayment or debt enforcement should be well targeted, for a fixed time period, and asset quality should be accurately recorded. Excessive regulatory/ supervisory forbearance should be avoided, and banks should be encouraged to prudently restructure loans to borrowers facing difficulties related to the pandemic, and to use existing liquidity and capital buffers. If prudential ratios fall below regulatory requirements, the supervisor should work with banks on a reasonable timeline and strategy to restore them.

In the aftermath of the pandemic, structural reforms should resume to secure SME financial inclusion and reduce the cost of financial intermediation. Achieving lasting SME financial inclusion could be a key source of sustainable and inclusive growth in the Kyrgyz Republic in the medium term. The analysis in this paper takes a closer look at the determinants of lending spreads and collateral requirements applied by banks to inform policymakers of potential reforms needed. 
The analysis identifies competition, capital, loan size, credit risk and deposit rates, as well as the legal framework, as key explanatory variables for interest rate spreads. Higher competition would pressure banks to lower spreads for a certain level of costs, given that otherwise there would not be an incentive to lower them but to keep high profits instead. Higher capital ratios are associated with lower spreads. Spreads could be reduced as the loan size increases which is most likely a reflection of the credit worthiness of borrowers. Also, lower credit risk (proxied by NPLs or loan loss provisioning) is associated with lower spreads. Lower level of interest rates (i.e. deposit rate) is associated with lower spreads. At the same time, while not tested due to lack of data, external funding costs are likely to be positively and significantly associated with spreads. Thus, it would be important to further increase competition by leveling the playing field, lower credit risk by strengthening the rule of law, and improve credit worthiness of borrowers and strengthen bank balance sheets through compilation of credit histories, and lower deposit rates and the cost of external funding by expanding the domestic funding base. Protection of property rights and an improvement in the overall business environment can lead to better business and financial rankings of the country and may mostly likely reduce external funding costs.

Lending spreads have tended to decrease over time, but remain relatively high for small and medium-sized banks. The decrease in spreads over time is likely due to improved competition, reflected in lower concentration in the market (i.e. a fall in the HHI). Smaller and medium-sized banks have much higher spreads, as the cost of funding and headcount per loan is higher than for larger banks. Given the high headcount, one way to reduce average cost is to increase access of a greater share of the population to banks. It would also be important for these banks to grow their domestic funding base and lengthen the maturity of deposits. Expanding ewallet technology could bring down funding costs. Given that the cost of external funding is high due to a 5-6 percent hedging cost, reducing that cost could also help reduce spreads. Absorption of smaller banks by larger and more efficient ones could potentially create synergies and economies of scale, helping to compress operating costs and reduce the spreads. Finally, operational efficiency could be enhanced by using digital footprints for credit scoring which can offer better information than credit bureau scores. ${ }^{4}$

More generally, alternative channels such as venture capital, private equity, and fintech, could facilitate greater SME financial inclusion. ${ }^{5}$ They could either support the supply of bank credit or open new financing channels. Traditional SME finance could be enhanced by: i) using big data analytics to facilitate the gathering and processing of large amounts of consumer

\footnotetext{
${ }^{4}$ Financial Inclusion of Small and Medium-Sized Enterprises in the Middle East and Central Asia, February 2019, Departmental Pa per No. 19/02.

${ }^{5}$ Financial Inclusion of Small and Medium-Sized Enterprises in the Middle East and Central Asia, February 2019, Departmental Pa per No. 19/02.
} 
credit performance; ii) artificial intelligence and machine learning that combine SME

registration and accounting information with geographical and socio-economic information to generate real-time credit scores; iii) promoting competition through new platforms that allow borrowers to compare credit cards, insurance, leasing, and other SME banking products. New financing channels, such as P2P/Marketplace and Business Lending, which are in an incipient phase in the Kyrgyz Republic, could provide online platforms to collect contributions from investors towards a loan to businesses.

Strengthening the rule of law and greater transparency on the creditworthiness of borrowers would also support a gradual relaxation of collateral constraints and credit

supply. Strengthening the legal framework for the enforcement of collateral claims could lead banks to relax collateral requirements. Banks could also rely more on information about borrower creditworthiness than on collateral via increased coverage by credit bureaus and use new of credit scoring technologies. The NBKR could then also consider relaxing collateral regulations to reduce the risk that such regulations may ration credit (from banks having reached regulatory limits but still able to meet credit demand from creditworthy borrowers).

\section{References}

R. Almarzoqi and S. B. Naceur, 2015, Determinants of Bank Interest Margins in the Caucasus and Central Asia, IMF Working Paper/15/87.

C. E. Alper, B. Clements, N. Hobdari, and R. M. Porcel, 2019, Do Interest Rate Controls Work: Evidence from Kenya, IMF Working Paper/19/119.

M. Cihak and R. Podpiera, 2005, Bank Behavior in Developing Countries: Evidence from East Africa, IMF Working Paper/05/129.

S. Claessens and L. Laeven, 2004, What Drives Bank Competition? Some International Evidence, Journal of Money, Credit and Banking, Vol. 36, pp. 563-584.

E. Dabla-Norris and H. Floerkemeier, 2007, Bank Efficiency and Market Structure: What Determines Banking Spreads in Armenia? IMF Working Paper/07/134.

G. Dell'Ariccia and R. Marquez, 2004, Information and Bank Credit Allocation, Journal of Financial Economics, Vol. 72, No. 1, 185-214.

A. Demirgüç-Kunt and H. Huizinga, 1999, Determinants of Commercial Bank Interest Margins and Profitability: Some International Evidence, World Bank Economic Review, Vol. 13, No. 2, 379-408.

A. Demirgüç-Kunt, L. Laeven, and R. Levine, 2004, Regulations, Market Structure, Institutions, and the Cost of Financial Intermediation, Journal of Money, Credit and Banking, Vol. 36, No. 3, 593-622.

R. G. Gelos, Banking Spreads in Latin America, Economic Inquiry, Vol. 47, No. 4, October 2009, 796-814. 
T.S. Ho and A. Saunders, 1981, The determinants of bank interest margins: theory and empirical evidence, Journal of Financial Quantitative Analysis Vol. 16, pp. 581-600.

T. Ho and Hans R. Stoll, 1980, On Dealer Markets under Competition, Journal of Finance, American Finance Association, Vol. 35(2): pp. 259-67, May.

H. Holzhacker and D. Skakova, Kyrgyz Republic Diagnostic, European Bank for Reconstruction and Development, May 2019.

P. Honohan, 2003, The Accidental Tax: Inflation and the Financial Sector, in: "Taxation of Financial Intermediation," ed. by P. Honohan, New York and Oxford: Oxford University Press.

R. Horvath, 2009, Interest Margins Determinants of Czech Banks, Institute of Economic Studies, Faculty of Social Sciences, Charles University, WP 11/09 (Prague).

International Monetary Fund, Financial Inclusion of Small and Medium-Sized Enterprises in the Middle East and Central Asia, Departmental Paper No. 19/02, February 2019.

International Monetary Fund, Kyrgyz Republic: 2019 Article IV Consultation, July 2019, Country Report No. 19/208.

F. Jamaludin, V. Klyuev, and A. Serechetapongse, 2015, What Drives Interest Rate Spreads in Pacific Island Countries? An Empirical Investigation, IMF Working Paper/15/96.

R. Levine, N. Loayza, and T. Beck, 2000, Financial Intermediation and Growth: Causality and Causes, Journal of Monetary Economics, 46, 31-77.

R. Levine, Financial Development and Economic Growth: Views and Agenda, Journal of Economic Literature, Vol. XXXV (June 1997), pp. 688-726; Finance and Growth: Theory and Evidence, National Bureau of Economic Research Working Paper No. 10766, 2004.

S. B. Naceur, Determinants of Bank Spreads in Azerbaijan, Selected Issues, IMF Country Report No. 14/160, 2014.

B. Ozturk and M. Mrkaic, SMEs'Access to Finance in the Euro Area: What Helps or Hampers?, IMF Working Paper/14/78.

K. Ross and J. A. Peschiera, Banking Sector Spreads and Bank Competition in Peru, in the book Peru: Staying the Course of Economic Success, 2015.

A. Saunders, and L. Schumacher, 2000, The Determinants of Bank Interest Rate Margins: An International Study, Journal of International Money and Finance Vol. 19, No. 6, pp. 813832.

World Bank/European Bank for Reconstruction and Development/European Investment Bank Enterprise Surveys, 2013 and 2019. 